\title{
Hogyan befolyásolja a kultúra az egészséget és a jóllétet? I. rész: Az egészség kulturális beágyazottsága
}

\author{
How does culture affect health and well-being? \\ Part I: Cultural Contexts of Health and Well-being
}

\begin{abstract}
A három részből álló cikksorozat további részei: „Il. rész: Táplálkozás, kultúra és egészség”, "Ill. rész: Környezet, kultúra és egészség"
\end{abstract}

Szerző: Vitrai József $₫$

Emberi Erőforrások Minisztériuma

Beküldve: 2017.06.20.

doi: 10.24365/ef.v58i2.158

Kulcsszavak: egészségkultúra, szakpolitika

Keywords: culture of health, policy

\section{BEVEZETŐ}

2015-ben a WHO Európai Regionális Irodája neves európai szakértőket kért fel az egészség és a jóllét kulturális beágyazottságával kapcsolatos tudományos tények áttekintésére, és erről szakpolitikusoknak szánt rövid jelentés összefoglalására. ${ }^{1,2} \mathrm{~A}$ WHO e lépését olyan előzmények váltották ki, melyek a kultúrának az egészséggel való szoros kapcsolatára hívták fel a figyelmet. ${ }^{3,4}$ Az újonnan felismert összefüggések érthetővé teszik, hogy a kultúra miért kapott kiemelt figyelmet a WHO globális és európai stratégiai dokumentumában is. 5,6

A WHO szakértői munkacsoportja által összeállított jelentés megismerése nemcsak a szakpolitikusoknak világíthat meg új összefüggéseket, hanem a népegészségüggyel kapcsolatba kerülő valamennyi szakember számára is tanulságos, hasznos lehet. Követve a jelentés szerkezetét, három rövid írás ismerteti a munkacsoport összefoglalóját: az első a kultúra fogalmának az egészség és a jóllét szempontjából adott értelmezését mutatja be, továbbá rámutat azokra a hiányosságokra, amelyek komoly akadályt jelentenek az egészség javításában, az egészségegyenlőtlenségek csökkentésében. A második cikk a kultúra és a táplálkozás, a harmadik a kultúra és a környezet kapcsolatát vizsgálja az egészség és a jóllét fejlesztése szempontjából. Mindhárom rész a döntéshozók számára megfogalmazott - az egészség és a jóllét kulturális beágyazottságának az egészségügyi szakpolitikában való figyelembe vételét előmozdító - beavatkozások ajánlásával zárul.

\footnotetext{
' Elfogadva Naci és loannidis (2015) meghatározását, a jóllét az egészség hagyományos értelmezésén túlmutató testi, lelki és szociális dimenziók mentén megélt pozitív életérzés. Beletartoznak még olyan választások, tevékenységek is, amelyek célja a vitalitás, a szellemi frissesség, a társadalmi helyzettel, a saját teljesítményünkkel való elégedettség növelése.
} 


\section{A KULTÚRA?}

Sokan hajlamosak a kultúrát a komolyzenével, a szépirodalommal vagy a képzőmúvészettel azonosítani. Az Egyesült Nemzetek Oktatási, Tudományos és Kulturális Szervezetének (UNESCO) meghatározása szerint azonban a kultúra ennél jóval több: „... a társadalomnak, vagy egy csoportjának különböző szellemi, anyagi, intellektuális és érzelmi jellegzetessége, mely a múvészet és az irodalom mellett magába foglalja az életmódot, az együttélés módját, az értékeket, a hagyományokat és a hiedelmeket." " A meghatározás kiemeli, hogy a kultúra nem egy nemzet, rassz, etnikum vagy vallás sajátossága, hiszen az említetteken túl a kultúra része a kimondott vagy kimondatlan vélekedések, elvárások összessége, melyek meghatározzák, hogyan értelmezzük a valóságot, irányítanak minket abban, mit tartsunk normálisnak vagy abnormálisnak, irányt mutatnak és célokat adnak életünknek. ${ }^{8} \mathrm{~A}$ kultúra összetevői meghatározzák önképünket, világnézetünket, azt az értelmezési keretet, amiben döntéseinket hozzuk, ami szerint cselekszünk a családban, a közösségekben, a munkahelyen, társas környezetünkben. ${ }^{9}$

A kultúra tehát mindenkire hat, ugyanakkor szavaival, cselekedeteivel mindenki alakítja is azt. Emiatt egy-egy közösség, társadalmi csoport kultúrája hol gyorsabban, hol lassabban, de folyamatosan alakul, és mindig befolyásolja az egyének és közösségek önmagukról és a világról alkotott véleményét, ezen keresztül gondolkodását és viselkedését.

Fontos hangsúlyozni, hogy magát a kultúrát a kimondatlan, rejtett normák, értékek miatt nagyon nehéz leírni, megismerni. Pontosan azért, amiért a kultúra több annál, mint amit meg tudunk fogalmazni róla, nehéz megismerni a feltételezéseket, a vélt igazságokat, és megérteni, hogy egyes csoportokban elfogadott értékek hogyan térhetnek el élesen egymástól. Az eltérések felismerése egyfelől segíthet alkalmazkodni a csoportok sajátosságaihoz, másfelől viszont félreértése, vagy az értékek különbözősége konfliktusokhoz vezethet.

Szervezetek, intézmények vagy akár szakmai csoportok rendszerint saját mikrokultúrát alakítanak ki, melyek sajátos gondolkodási mintákat és cselekvési gyakorlatot tükröznek. Ha nem próbáljuk megismerni a szervezeti kultúrákban ható, kimondott vagy kimondatlan hiedelmeket, vélekedéseket, akkor egy-egy beavatkozáskor akár az elvárttal ellenkező hatásra és viselkedésre is számíthatunk. Ilyen okokra vezethető vissza számos népegészségügyi beavatkozás sikertelensége, ezért fordulnak a szakemberek újabban a kulturális különbségek figyelembe vételére alapozott megközelítések felé.

\section{AZ EGÉSZSÉG ÉS JÓLLÉT KULTURÁLIS BEÁGYA- ZOTTSÁGÁRA VONATKOZÓ TUDÁS BŐVITTÉSE}

A hagyományos egészséghatás-vizsgálatok során többféle halálozási és megbetegedési adatot használnak a szakpolitikai döntések alátámasztására gyakran anélkül, hogy tisztában lennének a kultúrának az egyéni és társadalmi viselkedésben betöltött szerepével. Az ily módon készült jelentések és az arra alapozott szakpolitikák ugyan körültekintően elemzett statisztikai adatokon nyugszanak, de nem ismerve a népesség szubjektív tapasztalatait és igényeit, nem tudják helyesen megítélni, mi valósítható meg valójában a szakpolitika szintjén.

Válaszul a tények, a társadalmi igények és a szakpolitika közötti diszharmóniára, a kulturálisan eltérő európai országok megegyeztek olyan indikátorrendszer kidolgozásában, ami lehetőséget nyújt adatgyűjtésre mind az objektív, mind a szubjektív egészségről. A hagyományosan gyújtött adatok alkalmasak egy adott közösségben az elégedettség vagy a boldogság mérésére, azonban nem megfelelők a viselkedést meghatározó vélekedések és értékek jellemzésére. Anélkül hogy világosan látnánk, hogyan befolyásolja a kultúra az egészségfelmérésekben használt kérdőívek kialakítását illetve a kérdésekre adott válaszokat, az így nyert adatok pontos értelmezése különösen nehéz és csupán feltételezéseken alapuló. ${ }^{10}$

A fentieken túl hátrányos helyzetû népesség nincs megfelelően képviselve a vizsgálatokban - nemritkán az alacsony részvételi hajlandóság miatt, aminek hátterében egyrészt az ellenségesnek vélt környezet, másrészt a mindennapi túlélés okozta aggodalom áll. A felmérésekből való kimaradás oka lehet továbbá az iskolázatlanságból vagy eltérő anyanyelv 
miatti alacsony írás-olvasási vagy beszédértési készség. Ilyen helyzetekben az egészségfelmérés tovább növelheti a társadalmi egyenlőtlenségeket azáltal, hogy nem közvetíti a hátrányos helyzetű csoportok igényeit, érdekeit a döntéshozók felé. Az adatgyűjtés ilyen torzulása különösen nyilvánvaló bizonytalan társadalmi helyzetekben, amiket éhínség, klímaváltozás, nagyléptékű migráció vagy egyéb előreláthatatlan humán krízis okoz. llyenkor a társadalmi sérülékenység és egyenlőtlenség felerősödhet oly módon, hogy azt a hagyományos adatgyújtési módszerekkel nem lehet követni. Megfelelő tudás hiányában nem lehetséges a szenvedés helyi formáinak feltérképezése, így az adatok bizonyulhatnak akár félrevezetőnek is.

Eredményes, a kihívásokra megfelelően reagáló szakpolitikához a döntéshozóknak meg kell vizsgálniuk, hogy a közösségek - kultúrájuk által meghatározottan - hogyan alkalmazkodnak a különböző komplex társadalmi problémákhoz. A kvantitatív jellegű vizsgálatok adatainak helyes értelmezéséhez, a nem tudatos torzítások kiszúréséhez, a vizsgálati eszközök érvényességének megitéléséhez csupán a kvalitatív kutatási stratégiák kínálnak megfelelő keretet. Ezért nyilvánvaló, hogy innovatív és a célhoz illő kevert (kvalitatív + kvantitatív) kutatási módszertan alkalmazása elengedhetetlen a lakosság egészségének javításához. ${ }^{11}$

\section{AJÁNLÁSOK}

A kiegyensúlyozott és integrált adatgyűjtés és elemzés támogatása érdekében az alábbi nyolc szakpolitikai beavatkozást ajánlott figyelembe venni. Bár a javaslatok sorrendben állnak, az ajánlott lépések egymástól függetlenek és ismétlendők.

1. Támogassák a kultúra és az egészség közötti kapcsolat jobb megértését! Ehhez a kultúra olyan meghatározása szükséges, amely nem korlátozza azt sem etnikumra, sem rasszra, helyette hangsúlyozza, hogy a különböző szempontból (pl. életkor, lakóhely, foglalkozás) hasonló társadalmi-gazdasági helyzetben élők gondolatát, cselekvését kultúrájuk hasonlóan alakítja.
2. Alakítsanak ki megfelelő lehetőségeket és iránymutatást a döntéshozók számára felismerni saját kulturális elvárásaikat, és tudatosan kezelni azoknak az értékelést és döntéshozást befolyásoló hatását! Erre alkalmasak lehetnek önértékelési csoportok, diverzitás-képző programokon való részvétel, és más olyan tevékenység, amely növeli az önismeretet, és javítja a közös értékekre, gyakorlatra alapozott kommunikációt.

3. Járuljanak hozzá az egészség és a jóllét társadalmi és kulturális befolyásoló tényezőire vonatkozó tudás bővítéséhez a kevert módszerre fókuszáló társadalomtudományi kutatások támogatásával! Alkalmazzák az eltérő vélekedések vizsgálatát, a szubjektív tapasztalatok, mint értékes tények kutatására alkalmas módszerek kifejlesztését, továbbá a kvalitatív megfigyeléseknek a kvantitatív adatokba integrálását.

4. Használjanak fel szubjektív értelmezéseket, tapasztalatokat és vizsgálati adatokat az egészséget és jóllétet érintő szakpolitikákba, hogy jobban lehessen azonosítani az eltérő csoportok szükségleteit, értelmezni a kvantitatív eredményeket! Ehhez ki kell fejleszteni új sérülékenységet és ellenálló képességet felmérő stratégiát, továbbá nyitni érdemes interaktív kommunikációs csatornákat a kutatóknak, az egyéneknek és közösségeknek az egészséggel, a jólléttel, a betegségekkel valamint a gyógyítással kapcsolatos tapasztalatainak intenzívebb cseréjének elősegítéséhez.

5. Azonosítsanak olyan etikai problémákat, amelyek az egészség és az egészségügyi ellátás közötti értékkülönbségek miatt lépnek fel! Ehhez hozzanak létre könnyen igénybe vehető közéleti fórumokat ( $p l$. nyílt szakpolitikai fórum, internetes szakpolitikai vita), amelyeken a döntéshozók kisebbségi véleményeket is megismerhetnek a megelőzés és ellátásban való együttmúködés akadályairól. Gondoskodjanak az egészségügyi szakembereknek az eltérő kultúrájú társadalmi csoportok egészségügyi szükségleteinek felmérését, megértését és képviseletét célzó képzéséről.

6. Támogassanak olyan fejlesztéseket, amelyek bővítik a tudást a kultúra egészségre és a jóllétre kifejtett hatásáról, valamint biztosítják a 
szolgáltatások és szakpolitikák kulturális kompetenciájának mérését! A fejlesztések eredménye lehet kulturális kompetenciamérő eszközök, továbbképzések, tudáscsere-platformok és más támogató projektek. Az ilyen kezdeményezéseket célszerű mind kvantitatív (megfelelő indikátorokkal), mind kvalitatív (pl. narratív módszertannalii) módszerekkel értékelni.

7. Növeljék a kapacitásokat az interszektoriális együttmúködés előmozdítására a jóllétnek és a kultúrának az „egészséget minden szakpolitikába" megközelítés középpontjába állításával! Ezt a döntéshozóknak a „össztársadalmi és össz- kormányzati" megközelítés felé tett jelentős és jól felismerhető elkötelezettséggel kell demonstrálniuk.

8. Osszák meg a sikeres gyakorlatokról szerzett információkat! Az egészség és a jóllét kultúrára alapozott megközelítése szempontjából hasznos lehet többféle szemlélet és olyan új helyzetek megismerése, melyekben sikeres tevékenységek valósultak meg. A társadalomban új stratégiával és gyakorlattal kivitelezett sikeres megismételhető és változtatható léptékü - kísérleteket célszerű dokumentálni és terjeszteni.

\section{HIVATKOZÁSOK}

\footnotetext{
${ }^{1}$ Naci H, loannidis JPA. Evaluation of Wellness Determinants and Interventions by Citizen Scientists". JAMA. 2015;314(2):121-122. doi:10.1001/jama.2015.6160.

${ }^{2}$ Napier AD, Depledge M, Knipper M, Lovell R, Ponarin E, Sanabria E, Thomas F. Culture matters: using a cultural contexts of health approach to enhance policy-making. Policy brief, No. 1. Cultural Contexts of Health and Well-being. World Health Organization 2017.

${ }^{3}$ Davies SC, Winpenny E, Ball S, et al. For debate: a new wave in public health improvement. Lancet 2014;6736:1-7. doi:10.1016/S0140-6736(13)62341-7

${ }^{4}$ Napier AD, Ancarno C, Butler B, Calabrese J, Chater A, Chatterjee H et al. Culture and health. Lancet 2014;384:160739. doi:10.1016/S0140-6736(14)61603-2.

${ }^{5}$ The Sustainable Development Agenda [website].New York: United Nations; 2017; http://www.un.org/sustainabledevelopment/development-agenda/ (Elérve: 2017.06.15.)

${ }^{6}$ Health 2020: the European policy for health and well-being [website]. Copenhagen: WHO Regional Office for Europe; 2015. http://www.euro.who.int/en/health-topics/health-policy/health-2020-the-european-policy-for-health-and-wellbeing (Elérve: 2017.06.15.)

${ }^{7}$ UNESCO Universal Declaration on Cultural Diversity [website]. Paris: United Nations Educational, Scientific and Cultural Organization; 2001. http://portal.unesco.org/en/ev.php-URL ID=13179\&URL DO=DO TOPIC\&URL SECTION=201.html. (Elérve: 2017.06.15.)

8 Beyond bias: exploring the cultural contexts of health and well-being measurement. Copenhagen: WHO Regional Office for Europe; 2016. http://www.euro.who.int/ data/assets/pdf file/0008/284903/Cultural-contexts-health.pdf, (Elérve: 2017.06.15.)

9 Járomi, É. Szilágyi K, Vitrai J. Az egészségkultúra fogalma, vizsgálatának lehetőségei a köznevelési intézményekben. Szakirodalmi áttekintés. Egészségfejlesztés, 2015;56(5-6):2-13.

${ }^{10}$ Nussbaum MC. Who is the happy warrior? Philosophy poses questions to psychology. J Legal Stud. 2008;37(S2):S81113. doi:10.1086/587438.

${ }^{11}$ Adams V, Burke NJ, Whitmarsh I. Slow research: thoughts for a movement in global health. Med Anthropol. 2014;33(3):179-97. doi:10.1080/01459740.2013.858335.
}

\footnotetext{
ii Történeteken kitalálásán, meghallgatásán, értelmezésén alapuló módszerek
} 